\title{
ERDÉLYI TUDOMÁNYOS FÜZETEK
}

SZERKESZTI

DR. GYŐRGY LAJOS

1932. AZ ERDÉLYI MÚZEUM-EGYESÜLET KIADASA

49. SZ.

\section{A MEZŐGAZDASÁGI HITELKÉRDÉS}

RENDEZÉSÉRE IRÁNYULÓ TÖREKVÉSEK

\section{A ROMÁN TÖRVÉNYHOZÁSBAN}

IRTA :

DR. OBERDING JÓZSEF GYÖRGY

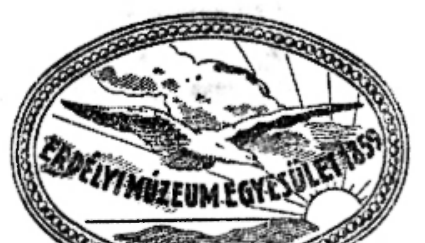

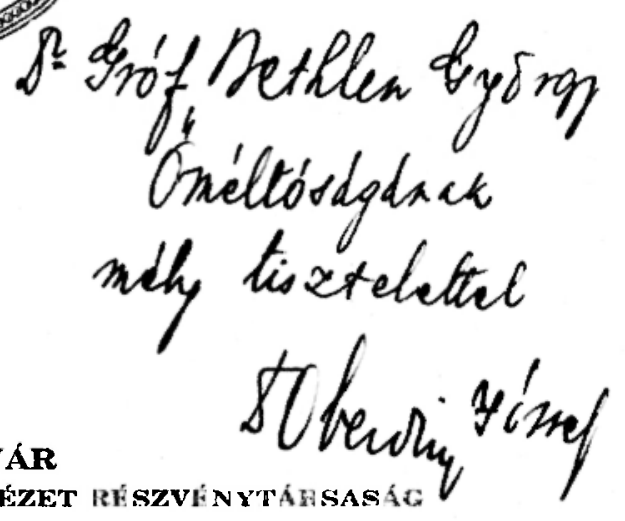

CL. UJ-KOLOZSVAR MINGRVA IROC AI. MI ES NYOMDAI MĆ
1932. 


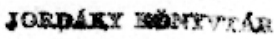

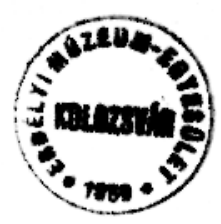


I.

A régi Románia mezỏgazdasági hitelszervezetét három földhitelintézet és 2901 népbank (hitelszövetkezet) alkotta. A földhitelintézetek a hosszú lejáratú hitelszükséglet, a népbankok pedig a rövidlejáratú, személyi hitelszükséglet kielégítéséröl gondoskodtak, a mezőgazdaság 8zolgálatára állott emellett még a Banca Nationala által folyósított visszleszámítolási hitelek 25 százaléka. A három földhitelintézet, a Prima Societate Civilà de Credit Funciar Rurar, a Banca Agricola és a Casa Rurară közül is azonban esak a két elöbbi tartozott a szorosan vett földhitelintézetek közé, mert a Casa Ruraràt az 1908. évi birtokreform pénzügyi lebonyolítására hívta életre az 1908. évi április 4-i törvény. A Prim? Societate Civilà de Credit Funciar Rurar 1873. évben alakult, az 1873. évi április 5-i fejedelmi dekrétum alapján, a Banc Agricola:neg az 1894. évi március 28-i törvény alapján.

A román mezőgazdasági hitelszervezet a békekötés után Romániához csatolt új területek révén csupán 787 hitelszövetkezettel gyarapodott, mert a csatolt területek mezőgazdaságát támogató földhitelintézetek mind a csatolt teriiletek volt fövárosaiban mükodtek. Ilyen körülmények között a mezögazdasági hitelszervezet távolról sem tudta a megnagyobbodott Románia mezögazdasági hitelsziikségletét kielégíteni, annál kevésbbé sem, mivel az imperium kiterjesztése után véqrehajtott földbirtokreform roppant felfokozta a mezögazdasági hitelkeresletet. Az agrárreform során az ország 20 millió hektărt kitevő termőföldjéböl több mint 6 millió hektárt osztottak szét a földnélküliek, illetve törpebirtokosok közt, a nélkül azonban, hogy a föld megmüveléséhez szükséges eszközöket rendelkezésükre bocsátották volna. Az új kisbirtokok beinstruálására vonatkozólag semminemü állami intézkedés nem történt, úgyhogy a földhöz juttatottaknak maguknak kellett birtokaikat felszerelniôk. Az új kisbirtokosok azonban csak rövidlejáratú hitelhez jutottak hozzá, melynek kamata a nagy hitelkereslet és a belföldi töke elégtelensége következtében a 35-40 százalékot is meghaladta. Ez a kamatláb még a hitelszövetkezeteknél sem volt alacsonyabb. Az agrárreform során földhözjuttatottak mellett megindult a kisajátítást szenvedett volt közép- és nagybirtokosok eladósodása is, egyrészt azért, mert meghagyott birtokukat belterjesebb gazdasággá kellett átalakítaniok, másrészt pedig, mert régi életszínvonalukat 
nem tudták a minden átmenet nélkül lecsökkent jövedelmükkel összhangba hozni. Ehhez járult még az agrárperek költsége is, melytöl úgyszólván egyetlenegy kisajátítást szenvedett birtokos sem tudott mentesülni a kisajátítás mértéke vagy a kisajátítási ár törvénytelen megállapítása miatt.

A mezőgazdaság eladósodása ilyen körülmények között rövidesen oly méreteket öltött, hogy sürgős és hathatós kormányintézkedést tett szükségessé. A kormány a megoldást a mezögazdasági hitelszervezet kibövítésében látta célravezetönek, különösen a földhitelintézetek számának szaporítása útján, mert a mezögazdaság a hitelt legnagyobb mértékben beruházások céljára vette igénybe s éppen az e célt szolgáló hoszszúlejáratú mezögazdasági hitelellátás volt a leghiányosabb. A földhitelintézetek szaporítāsa egyrészt pótolta volna a hosszúlejáratú mezőgazdasúgi hitelellátás hiányosságát, másrészt pedig módot nyujtott volna arra, hogy a mezögazdaságot terhelö terhes rövidlejáratú hitelek hosszúlejáratú amortizációs kölesönökké alakíttassanak át.

Minthogy azonban a kormány újabb földhitelintézetek alapításában nem akart érdekeltséget vállalni, a kérdés megoldását a magántöke vállalkozási kedvére bízta a magánföldhitelintézetek alapításáról szóló tör. vény megalkotása útján. Az 1923. évi június 27 -i magánföldhitelintézetek alapitásáról szóló törvény áttöri a földhitelintézetek eddigi privilégizált jogi helyzetét $\mathbf{s}$ lehetőséget nyújt a magántőkének is a földhitelin. tézetek alapítására, csupán azt köti ki, hog̣v a magánföldhitelintézetek alapításában csakis gazdák és mezögazdasági intézmények vehessenek részt. A magánföldhitelintézetek a törvény vezetöelve szerint a gazdák önellátó hitelszervezete lenne, tartalmilag szövetkezeti jelleggel, de részvénytársasági formában. A törvényhozás valószínünek vélte, hogy egy ilyen jellegứ intézet könnyen megnyeri a magántökések bizalmát és az intézet tőkeszerzési tevékenysége sem fog akadályokat találni.

\section{A magánföldhitelintézeti törvény.}

Az 1923. évi június 27-i törvény szerint - mint említettük - a földhitelintézetek alapításában csak földbirtokosok, illetve mezögazdasági eggyesületek és társulatok vehetnek részt, legalább 100 olyan földbirtokos kơzremúködésével, akiknek földbirtoka 50 millió lej értéket képvisel. A társaság jogi formájául a részvénytársaságot állapítja meg a törvény, az alaptőkét 20 millió lejben minimálva.

A földhitelintézetek célját a következőkben jelöli meg a törvény:

1.) földhitelt nyujtani záloglevelek kibocsátása útján,

2.) a föld bármely irányú kihasználását és a mezögazdasági termé kek ipari termékké való feldolgozását finanszirozni,

3.) fenti vállalkozások és ipari munkák végzése és finanszirozása,

4.) közraktárak és gyűjtöállomások létesítése a mezögazdasăgi termények és a mezőgazdasági ipari termékek részére,

5.) bármilynemủ bankmüveletet végrehajtani a társaság tagjaival, valamint a mezőgazdasági társaságokkal és mezőgazdasági egyesületekkel, 
6.) mezögazdasági biztosítások eszközlése,

7.) váltótárcájuk visszleszámítolása a Banca Nationalanál, bár a váltón egy aláirás is szerepel a bank aláírásán kivül,

8. zẩogkölcsönök folyósítása kizárólag a társaság tagjai számára, bármi ynemü mezőgazdasági terményre, illetve azok ipari termékeire, valamint állatokra és a 2 . bekezdésben említett vállalatok és iparok összes termelő felszerelésére.

A törvény a földhitelintézeteknek széles munkakört biztosított. Az ingatlanjelzálog hitelnyujtás mellett felhatalmazást ad ingójelzálog és váltóhitel nyujtására is, a hitelnyujtás formája lehet hosszú és rövidlejáratú hitel. Hatáskörükbe utalta továbbá mezögazdasági, ipari- és kereskedelmi vállalatok alapítását és finanszirozását, sőt a mezőgazdasági biztositást is.

A fenti törvény alapján a Banca Ipoteca Rurara Societate Civilă de Credit Funciar Rurar alakult meg 1927. évben és újjá szervezték a Prima Societate Civilă de Credit Funciar Rurart is. A záloglevélemisszió azonban egyik intézetnek sem sikerült, mert a törvény az adók behajtásáról szóló törvény 24. szakaszát, mely mindennemí jelzálog bejegyzés előtt az adókövetelésekre nézve prioritást biztosít az állam számára, nem szüntette meg, $\mathrm{s}$ ennek következtében a külföldi pénzpiac nem volt hajlandó felvenni a román zálogleveleket. Ahhoz, hogy a záloglevelek külföldön plasszirozhatók legyenek, a külföldi tökeérdekeltségek még adó- és illetékkedvezményt is kívántak.

A fenti törvény tehát nem váltotta be a hozzáfüzött reményeket. A Banca Ipoteca Ruraran kívül egyetlen egy új magánföldhitelintézet sem alakult, de a záloglevél emisszió ennek az intézetnek sem sikerült az államnak az adótörvényben biztosított prioritási joga miatt. A kormány azonban hallani sem akart az állami elöjog korlátozásáról, közben pedig a mezögazdaság eladósodása egyre nagyobb és nagyobb méreteket öltött. A mezögazdasági hitelkérdés rendezésére nézve nem is történt újabb kísérlet, míg a nemzeti parasztpárt nem került kormányra.

Az ủj kormány a mellett, hogy mindazon akadályokat, melyek a mađránfödhitelintézetek alapítását gátolták, elhárította, belátta, hogy a mezőgazdasági hitelkérdés megoldását nem lehet tisztán a magán tởke vállalkozási kedvétöl várni s azért a kérdés megoldásában szerepet vállalt maga is.

\section{Az új magánföldhitelintézeti és a mezőgazdasági hitelintézeti törvény.}

$\mathrm{Az}$ új kormány új alapokra helyezi az egész mezögazdasági hitelkérdést. Atdolgozza az 1923. évi jứnius 27-i magánföldhitelintézetekről szóló törvényt s e mellett új földhitelintézeti típusit is kreál mezögazdasági hitelintézet néven. A magánjogi földhitelintézetel mellett, melyek továbbra is a földbirtokosok szabad alapitása útján létesülhettek, a mezögazdasági hitelintézet alapitạ́sában az állam is közremüködik. Az új törvény mint a földhitelintézetekről és a mezögazdasági hitelintézetekröl szóló 1929, évi augusztus 20-i törvény 
került a törvénytárba. Mindkét fajta intézet célját a mezögazdasági termelés és a mezőgazdasági ipar hitelszükségletének kielégítésében s ezek fejlődésének elömozdításában jelöli meg a törvény.

Magánjogi földhitelintézetet, épúgy mint azt 1923. évi június 27-i törvény értelmében, legalább 100 olyan földbirtokos alapithat, akik nek birtokai legkevesebb 50 millió lej értéket képviselnek, a részvényjegyzésben résztvehetnek továbbá a inezőgazdasági társaságok és egyesületek mellett a mezögazdasági- és hitelszövetkezetek is. Az alaptóke szintén 20 millió lejben van minimálva.

A mezögazdasági hitelintézetek alapításában az állam mellett közhasznú, vagy közintézmények, pénzintézetek és magánosok is résztvohetnek. A mezögazłasági hitelintézet minimális alaptökéjét 500 millió lejben állapítja meg a törvény.

A magánföldhitelintézetek ügyletköre a következőkre terjed ki:

1.) Az intézet mezögazdasági területekre jelzálogkölcsönöket adliat készpénzben, vagy záloglevelek kibocsátása utjân, akár hosszúlejáratra fizetendő annuitások ellenében, akár rövidlejáratra, amortizációkkal, vagy a nélkül;

2.) zálogkölcsönöket folyósíthat a mezögazdák mindennemü mezögazdasági termékére $\mathrm{s}$ azok ipari származékára, valamint állataira és a mezőgazdasági üzemek egész termelö berendezésére;

3.) kölcsönöket engedélyezhet a Központi Szövetkezeti Banknak és a hitelszövetkezeteknek abból a célból, hogy ezek az intézetek a kisbirtokosok számára személyi hitelröl gondoskodjanak;

4.) a föld hasznosítását és termékei ipari feldolgozását célzó vállalatokat és szövetkezeteket pénzügyileg támogathat;

5.) a társaság tagjaival mindennemü bankári müveletet lebonyolíthat, zálogleveleket és az általuk kiállított kötelezvényeket kézizálogba elfogadhatja;

6.) a közgyülés jóváhagyásával kötvényeket bocsáthat ki a készpénzben folyósított kölcsönờ vagy a társaság ingatlanai alapján.

A mezögazdasági hitelintézetek ugyanazon ügyletekkel foglalkozhatnak, mint a magánföldhitelintézetek, kivéve a fenti 5.) pontban emlí. tett bankári müveleteket.

Mindkét intézet kölcsönei a biztosítékul felajánlott birtok forgalmi órtékének fele erejéig (erdőknél, szőlőknél annak egyharmadáig) engedélyezhetök, az ingójelzálogkölcsönöknél a zálogtárgy értékének egyharmadáig.

A törvény legnevezetesebh intézkedése a földhitelintézetek számára a jelzálogos ingatlan minden jövedelmére és termékére, valamint annak egész felszerelésére biztosított elsöbbségi jog, melyet egvedull csak az állam 3 évről hátralékos egyenes adókövetelése elöz meg. Elsőbbséget bizto sít a törvény a földhitelintézeteknek az ingójelzálogoknál is, ugyanesak az állam 3 évre visszamenő egyenes adóját kivéve minden más követeléssel szemben, eltekintve a tulajdonosnak a legutolsó év haszonbér követelésétől. A jelen törvény alapján alakulandó intézetek számára biztosított további kedvezmények kozt, ami szintén ujítás az 1923. évi június 27-i törvénnyel szemben, a következők szerepelnek: teljes bélyeg- 
és illetékmentesség az alapítási okmányok, részvények, záloglevelek, kötvények, jelzálogadóslevelek, kézi- és jelzálogszerződések, vevények, kimutatások, lajstromok, bírósági kérvények és keresetek, végrehajtási okmányok stb. számára. A magánföldhitelintézetekröl szóló törvény átdolgozásánál az új kormány már figyelembe vette mindazokat a kívánságokat, - mint látjuk - melyeket a külföldi tökeérdekeltségek hangoztattak.

A törvény elöírja továbbá, hogy az 1923. évi június 27-i törvény alajjár müködő intézetek a törvény megjelenésétől számított 6 hónapon belül kötelesek alapszabályaikat jelen törvénynek megfelelöen átalakítani, különben elvesztik minden kedvezményüket és elöjogukat. Zálogleveleket a jövóben csakis az ezen törvény szerint alakult intézetek bocsáthatnak ki, azok a magánintézetek pedig, melyek a multban már bocsátottak ki zálogleveleket, újabb kibocsátásokat mindaddig nem eszközölhetnek, míg külön törvény nem állapítja meg számukra a kibossátás elöfeltételeit.

Az immár módosított magánföldhitelintézeti törvény sem talált azonban visszhangra a gazdatársadalom körében; a törvény nyújtotta lehetőséget egyedül csak az erdélyi magyar gazdák igyekeztek kihasználni. A magyar gazdatársadalom 1929. év őszén akciót indított, hogy a fenti törvény alapján Erdélyi Magyar Földhitelintézet céggel létrehozhassa a maga mezögazdasági hitelellátó intézményét, $\mathrm{s}$ bár az alaptőke teljes összegben lejegyzést nyeit, a később teljesen leromlott gazdasági viszonyok folytán a részvényjegyzök részvénybefizetési kötelezettségüknek már nem tudtak eleget tenni, úgyhogy az akciót végül is likvidálni kellett.

Nagry nehézségekbe ütközött az állami hozzájárulással tervezett mezögazdasági hitelintézet megalapítása is, mert a külföldi tökeérdekeltségek sokáig vonakodtak résztvenni az intézet megalapításában. Közel két évig húzódó tárgyalás után végre 1931. év márciusában mégis sikerült a külfölldi tökeérdekeltségekkel megállapodásra jutni s az intézetet végleges formájában Creditul Agricol Ipotecar al României céggel 330.000 arany lej alaptökével életre hívni. A Creditul Agricol Ipotecar al României felállítását az 1929. évi augusztus 20 -i törvényt kiterjesztö 1931. évi március 18-i törvény szabályozza.

\section{A Creditul Agricol Ipotecar felállítására vonatkozó törvêny.}

Ez a törvény 4 paragrafusból áll. Az 1 . \$ kimondja, $\mathrm{k}$ gy a Creditul Agricol Ipotecar mezőgazdasági hitelintiézetnek ismertetik el. A 2. §. szerint a Creditul Agricol Ipotecar a földhitelintézetek és a mezögazdasági hitelintézetek szervezetéröl szóló 1929. augusztus 20-i törvény rendelkezései alá tartozik s élvezi annak minden elönyét, kivéve azokat a pontokat, melyeket az alapszabályok hatályon kívül helyeznek, valamint hatályban maradnak erre nézve a kereskedelmi törvény ama rendelkezései is, melyeket az alapítóokirat, az alapszabályok és az 1929. augusztus 20-i törvény hatályon kívül nem helyeznek. A 3 . צ. az állam garanciáit tartalmazza, melyek a következők: a) az állam az intézet el- 
söbbségi részvényei után harminchárom évi időtartamra arany lejben fizetendő évi $7 \%$-os osztalékot garantál, mely minden jelenlegi és jövőbeli román adó alól mentes; b) garantálja az állam az intézet által kibocsátandó összes kötelezvények után járó kamatokat, valamint a kibocsátási szerződések feltételei szerinti törlesztési részletek pontos fizetését az intézet fenállásának egész idótartama alatt, garantálja a fent említett kötvények elöleges automatikus beváltását kicserélés esetében, amennyiben az a kötelezvények tuljadonosaira nézve sérelmesnek ismertetnék el, akár a román törvényhozás, akár a társaság alapszabályai rendelnék el a kieserélését. Az állam kötelezi magát továbbá, lıogy más hasonló társaságok kötelezvényeit, kivéve a Banca Agriculturii Românesti kötelezvényeit, mely intézet egyidejüleg alakul meg a mezőgazdaság szanálása céljából, nem garantálja. UUgyanesak ez a paragrafus mondja ki, hogy az intézet alapszabályai a Nemzetközi Mezögazdasági Hitelintézet üzletkörébe való bevonása érdekében módosithatók, de azzal a feltétellel,hogy a módosítások az elsőbbségi részvényesek és a kötelezvények tulajdonosainak jogait ne sértsék. A 4. \$. felhatalmazást ad a pénzügyminiszternek, hogy a Casa Autonoma a Monopolurilor Regatului României által kibocsátott 1931. évi fejlesztési kölesön terhére 200 millió francia frank értékben aláirhasson, vagy vásárolhasson az intézet által kibocsátandó kötelezvényt, továbbá, hogy az 1931. évi közgazdasági és pénzügyi fejlesztési programmban irt feltếtelek szerint megköthesse a szükséges megállapodásokat és megtegyen minden intézkedést, melyeket ezeknek a kötvényeknek vásárlása és aláirása, valamint azoknak beváltása szükségessé fog tenni.

A törvénynek két melléklete van, az A) és B) melléklet. Az A) melléklet az alapító okirat, a B) melléklet az alapszabály.

$\mathrm{Az}$ alapító okirat megállapítja az egyes részvényjegyzőknek az intézet alaptókéjéhez való hozzájárulását. A 330 millió arany lej alaptôkéböl az állam 170 millió lejt jegvez, mégpedig 33.000 rendes részvény és 1000 elsőbbségi részvény ellenében. A részvénytőke másik, 160 millió lejt kitevő részét a különböző külföldi bankérdekeltségek jegyezték le, akik mind elsóbbségi részvényt kapnak, kivéve a lejegyzésben résztvevő egyedüli belföldi pénzintézetet, a Banca de Credit Românt, mely a lejegyzett 10 millió lej ellenében 1000 rendes és 1000 elsóbbségi részvényt kap.

A B) mellékletet képező alapszabály legfőbb intézkedései a kölcsönök feltételeire és az intézet által kibocsátandó kötelezvényekre vonatkoznak.

A társaság kétféle kölesönt folyósít: hosszúlejáratú törlesztéses kölesönt 10 évtőll 30 évig, és rövidlejáratú liölasönt, mely szintén lehet törlesztéses kölasön. Ezek a kölcsönök készpénzben folyósíttatnak.

Kölcsönök csak első helyre folyósíthatók s azok konverzió célját is szolgálhatják, ha a konverzió után az intézet követelése elsố helyre kerül.

A Creditul Agricol Ipotecar azonban mind ezideig csak formailag létezik, mert a megalakulása után bekövetkezett gazdasági válság lehetetlenné tette müködése megkezdését. 


\section{Ax țj szövethezeti törvény.}

A nemzeti parasztpárti kormány az új magánföldhitelintézeti és a mezögazdasagi hitelintérzetekröl szóló törvény mellett új szövetkezeti törvényt is alkotott, melynek a hitelszövetkezetekre vonatkozó szakaszai szintén a mezögazdasági hitelkérdés elömozdításának célját szolgálják.

Az 1929. évi március 28-i új szövetkezeti törrény új hitelszövetkezeti központot szervez Banca Centrală Cooperativă (Központi Szövetkezeti Bank) céggel, 500 millió lej alaptökével. Az alaptőke felét az állam jegreate le, a másik felét pedig a régi alaptöke és a Banca Naţionala hozzáínulúsa taszi. Kötelezi a törvény továbbá a Casa Centrală a Asigurärilor Sociale-t (Központi Sxociális Biztosítási Pénztár), hogy alapjainałk 30 százalékát gyümölcsöztetés céłjából a Banca Centrală Cooperativunál helyezze el. Az abaptokének az állam részéröl befizetett összege ưtán járó oszatalék szövetkezeti propagandâra és szövetkezeti szakoktatášra fordítandó, valamint az évvégi tiszta nyereségnek az osztalékok levonása és a tartalékalap dotálása után fennmaradó részének 30 százaléka is ezt a célt szolgálja.

Mix a Banca Centrală Cooperativă kizárólag a szövetkezetek pénzügyi támogatására van hivatva, a szövetkezetek irányítását és ellenörzését az Oficiul National al Cooperafiei Române (Román Nemzeti Szövetkezeti Hivatal) látja el. A szövetkezetekmek jogukban áll bizonyos csoportonként önálló ellenőrzői köteléket is létesítení, $\mathbf{s}$ ebben az esetben nem közvetlenül, hanem az ellenöri köteléken keresztül állnak az Oficiul National al Cooperaţiei Române ellenörzése alatt. Megengedi az új szövotkezeti törvény továbbá azt is, hogy a esatolt területeken levő régi központokban múkởdő szövetkezetek, mint amilyen például az erdélyi magyar hitelszövetkezeteket magába tömörítö Gazdasági és Hitelszövetlezetek Srövetsége, 1938. évig továbh mủködhessenek régi központjaikban, csupán ezen központokat kötelezi a Banea Centrală Cooperativă tagjai sorába való belépésre.

Az új szövetkezeti törvény rendkívül nagy fejlödési lehetôséget biztosít és messzemenő kedvezményeket nyujt a hitelszövetkezeteknek; sajnos, a pénzügyi támogatás tekintetében nem történt oly gondoskodás, mely lehetövé tette volna számukra a hitelszükséglet fokozottabb mér-

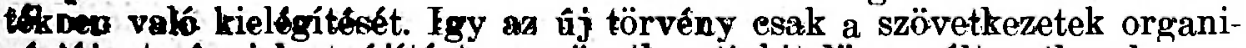
úbiớja terên jelent újítást, a szồvetkezeti hỉbelügy vâlltozatlanul megmaradt a rếgi vérssegény állapiotában.

\section{II.}

Ha végigtekintünk az elöbb ismertetett törvények során, nem tagadhatjok mog elismerdaünket hívalóséguk iránt. Mind az új magánföldhitelintúseti törvény, mind az állæmi tấmogatâs elvén nyugvó mezögazdasági bitelinténeti, illetve ennok grahorlati megvalósítása érdekében alkotott Creditul Agricol Ipotecar felällításáról szôló, valamint az ủj szövetkezeti törvłny kitünö alapot myujtottak volna a mezögazdasági hitelkérdésnek

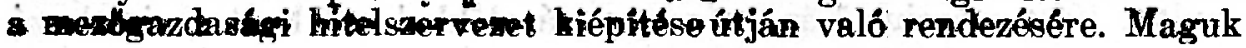


a törvények azonban még nem jelentik egyben a kérdés megoldását is, mert a törvény egymagában csak félintézkedés. A törvénynek életet a gyakorlat ad. Sajnos, egyrészt az állam elhibázott gazdaságpolitikája kơvetkeztében, -- mely az ország gazdasági leromlását eredményezte - másrészt pedig a bekövetkezett gazdasági világválság folytán a fenti törvények egyikébe sem tudott a gyakorlat életet önteni, úgyhogy a mezögazdasági hitelügy lényegében továbbra is megoldatlan maradt, a holt törvények mit sem változtattak a helyzeten.

Amilyen mértékben romlottak a gazdasági viszonyok, olyan mértékben súlyosbodott a mezögazdasági hitelkérdés is. A mezőgazdasáģi termények áresése folytán a mezögazdasági üzemek korábbi keletủ adósságai egyre súlyosabb teherként nehezedtek a gazdákra, akik egy bizonyos idön túl nemcsak, hogy törleszteni nem tudtak, de már a kamatfizetés is súlyos kötelezettséget jelentett számukra. A bankok viszont mind türelmetlenebbül léptek fel adósaikkal szemben; ez az eljárás a fizetöképességében teljesen legyengült gazdatársadalmat az anyagi összeomlás rémével fenyegette.

Ilyen körülmények közt a mezögazdasági hitelkérdés rendezésére irányuló törekvések is más megoldást követeltek. A mezögazdasági hitelkérdésnek a mezögazdasági hitelellátás rendezése útján való sikertelen kísérlete után az egyre súlyosbodó viszonyok folytán a hitelkérdés fö. problémáját most már nem a hitelellátás, hanem az adósvédelem, a mezőgazdasági üzemek szanálásának kérdése alkotta. Ha már a mezögazdaságon nem lehetett megfelelö kölcsönökkel segíteni, a törvényhozás egyre fokozottabban veszi védelmébe a gazdákat hitelezöikkel szem. ben s fötörekvése az eladósodott mezögazdasági üzemek szanálása felé irányul.

A törvényhozás mindenekelött a kamatkérdést rendezi, mint a leg. sürgösebb megoldásra váró kérdést. Akkor ugyanis, amikor a mezögaz. daság jövedelmezösége már úgyszólván teljesen megszünt, a bankkamat még mindig 22-24 százalékot tett ki. A kamatkérdést az 1931. évi április 2-i kamattörvény szabályozza.

\section{A kamattörvény.}

A kamattörvény a törvényes és szerződéses kamat kategóriáját állítja fel. A törvényes kamatot polgári ügyekben 1 százalékban, kereskedelmi ügyleteknél 2 százalékban; a szerződéses kamatot pedig (melynek írásbeli szerzödésben kell létrejönnie) 6 százalékban állapítja meg a Banca Natională mindenkori kamatlába felett. Aki ennél magasabb kamatot számít, uzsoravétséget követ el, melyre rendkívül súlyos szankciókat állít fel a törvény.

A hitelkérdés rendezésére irányuló összes eddigi törvények között a kamattörvény volt az egyedüli, melynek a gyakorlati élet hasznát vette. Minthogy a törvény életbeléptetésekor a Banca Nationala visezleszámítolási kamatlába 8 százalék volt, a törvény életbelépése után a megengedett legmagasabb kamat 14 százalékot tett ki, ami egy év mulva, 1932. március 1-én, még egy százalékkal csökkent a vissalegźa- 
mítolási kamatláb egy százalékkal való leszállítása folytán. Az kétségtelen, hogy a súlyos viszonyok között még a 14 százalékos kamat is túlmagas volt, de a 22-24 százalékos kamattal szemben mégis csak kcnriyítést jelentett.

A kamattörvény azonban, mint adósvédelmi intézkedés, csak részletintézkedést jelentett a mellett a nagyfontosságú feladat mellett, mely az eladósodott mezögazdasági üzemek szanálásának kérdését volt hivatva megoldani. A mezỏgazdasági üzemek szanálásának kérdését konverzió útján kívánta a törvényhozás megoldani. A törvény elgcr.dolása szerint a konverziót egy új pénzintézet, a Banca Agriculturii Românessti, hajtaná végre oly módon, hogy a konverzióra jogosult gazdák adósságát az intézet venné át és fizetné ki a hitelezöknek, a konvertált adós pedig 30 év alatt törlesztené le a tartozását az intézetnek. A mezögazdasági adósságok konverziójának lebonyolítására hivatott Bancì Agriculturii Româneşti felállításáról és a konverzió végrehajtásának módozatáról az 1931. évi április 9-i törvény intézkedik.

\section{A Banca Agriculturii Românești felállításáról szóló törvény és a mezőgazdasági adósságok konverziója.}

A Banca Agriculturii Româneşti kezdő alaptökéje 650 millió lej, melyet teljes összegben az állam jegyez le és fizet be. Az alaptőke további részének lejegyzésében a pénzügyi intézmények lés magánosok is résztvehetnek. Az állam által jegyzett összeg egyetlen elidegeníthetetlen részt alkot és az arra eső üzleti nyereség az első 30 év alatt a konvertált adósok kamatainak csökkentésére, valamint azon adósok kamatainak fedezésére fordítandó, akik önhibájukon kívül nehéz helyzetbe jutottak.

A mezögazdasági adósságok szanálását oly módon hajtja végre a bank, hogy a gazdák rövidlejáratú és abnormisan magas kamatozású adósságát hosszúlejáratú, maximálisan 30 évre terjedö és legfeljebb 12\%-os annuitású kölcsönné konvertálja a tartozásoknak engedmény vagy más helyett való fizetés átvétele útján.

A konverzió közelebbi feltételei a következők:

a) az egyes adósok összes tartozása ne lépje túl azt az összeget, melyet gazdaságuk nyershozadékának átvételekori értéke $36 \%$-ával törlèszthet, a hozadékmennyiséget illetően az előző évek átlagát, a törlesztést illetően pedig 30 évre szóló $12 \%$-os amortizációt véve alapul.

b) a tartozás ne lépje túl az adós egész gazdasága értékének $50 \%$-át, ha a tartozás törlesztiésének határideje nem haladja túl az 5 esztendőt, vagy az adós földje értékének $50 \%$-át, ha ez a határidő hosszzabb.

c) a tartozás átalakításának megtörténtével a vállalkozás jövedelmezővé váljék, vagyis a gazdaságnak az előzỏ évek átlaga szerinti terméseredménye, illetve annak értéke - folyó árak mellett — haladja meg a gazdaság termelési költségeinek, valamint a kamatok lés az iij tartozás törlesztési részletének együttes összegét. 
Az engedmény útján átvett követelések kifizetése megezyeźs suerint a következőképpen történik:

a) készpénzben,

b) akként, hogy a bank az engedményezỏ hitelezö nevére folyószámlahitelt nyit,

c) a banknak határidöre szóló kötelezettség vádłalása mellett, váltók vagy fokozatosan esedékes okiratok alapjún, vasy akként, hogy ax engedményezố hitelező javára határidóre szoló folyóssámla hitelek nyittatnak, és

d) konverziós címletekben.

A szanálás keresztülvitelét az adósnak kell kérnie a banktól, kimutatva adósságainak összegét, hitelezőit, a követeléselenek és biztuaitékoknak természetét, a kamatot és fizetési hatăridöt, valamint azt a körülményt, hogy foganatosittatott-e ellene végrehajtás, vagy sem, s az esetleges végrehajtás állapotát. A szanálás végrehajtásáról a bank a törvényben leszegezett irányelvek betartása mellett szabadon dönt. Hia hajlandó a szanálást keresztülvinni, előzetes megállapodást köt az adóssal, melyben a bank kötelezi magát a meghatározott feltételek mellett az adós tartozásának átvételére s ezzel annak törvẻnves megbízottjává válik. A szanált adós gazdaságának racionalizálása érdekében a bank a követelések átalakításával egyidejüleg a hitelszerződésbe technikai természetü feltételeket is bevesz, melyek a meztogazdasági termelés javítását és fokozását célozzák.

A bank a szanáláis céljaira szükséges tökét a következö passzív müveletekkel szerezheti meg:

a) kötelezvényeket bocsáthat ki a társaság alaptỏkéjének háromszorosáig,

b) betéteket fogadhat el legalább egy évi lekötéssel,

c) konverziós cimleteket bocsáthat ki jelzálogilag biztosított követelése erejéig,

d) kötelezettségeket vállajhat vádtỏk és fokovatosan eseckekes okiratok útján, vagy határidős folyószámlák nyitása által, melyeket a szanált adós reális garanciái biztosítanak,

e) átveheti végül a kézizálogra kölcsönzött pénztárak, valamint az Átmeneti Jelzáloghitelintézet összes követeléseit és tartozásait, továbbá más mezőgazdasági hitelintézeteknek az állam által átvett váltótárcáját és azt hitelmưveleteinek keretébe illesztheti.

A Banca Agriculturii Româneşti a törvény kihirdetése után megalakult ugyan, de feladatát, a mezőgazdasági adósságok konverziơjẩî́t nem oldhatta meg, mert a konverzióhoz szïkséges anyagi alapot nem tudta a kormány elöteremteni, sö́t, amint utóbb kiderüilt, az intézet alaptökéjére szánt 650 milliót is egyéb célokra használták fel. Az idöközzren katasztrófális méreteket öltö mezögazdasági válság következtében azonhan a törvényben szabályozott megoldás különben sem lett volna kielé. gítö, mert a föld- és mezögazdasági termények rohamos árzuhanása folytán a gazdáknak osak elenyészb̉en csekély nésze felelhetett meg a konverzió törvényszerinti elöfeltételének.

Az 1931. év nyarán uralomra került Iorga-kormány teljesen új ala- 
połra feltetto a mezögazdasági adósságok konverziójának ägyét. A törvénytervezet elgondolása szerint más és más eljárás alá esilk a 10 holdon aluli és az azon felüli gazdeadósságok konverziója. Mig a $10 \mathrm{hal}-$ don aluli gazdák u. n. jogszerinti konverzióban részesülttek volna, me tyet as állam hajt végre tekintet nélkül a hitelezök beleegyezésére, a 10 holdon felüli gazdák adóssága csakis a hitelezök hozzájảrulásával és a Banca Agriculturii Româneşti közremüködéséved konvertálható. A 10 holdon aluli kisgazdák jogszerinti konverziója azért vált szüikségessé, mert azok eladósodása, illetve aktiváik értékcsökkenése oly nagy volt, hogy vagyonuk a legtöbb esetben már nem fedte tartozásaik ësszót, indokolt volt tehát az önhibájukon kívül ily súlyos helyzetbe jutota kissazdáknak a hitelezökkel szemben való törvényes védelme.

A 10 holdon aluli gazdák konverzióját úey oldotta meg a törvénytervezet, hogy adósságuk a törvény életbelépése pillanatábán automatikusan 30 éves lejáratú és 4 százalékos kamatozású törlesztéses kölesönné alakul át. A régi hitelezőket az állam elégíti ki, az adósoktól pedig az évi törlesztési részleteket közadók módjára hajtja be. A 10 holdon felüli birtokosoknak viszont maguknak kell kénelmezniök a konverzió keresatülvitelét az e célra alakítotit speciális bizottságtól, adósságaik azonban asak abban az esetben konvertálhatók, ha a hitelezók követelésük $25 \%$-át elengedik és a konverzióhoz a tartozások összegének 55 százalékát képviselö hitelezök hozzájárulnak. Konverzió alá csak oly tartozások eshetnek, melyek földszerzés, ẻlö- és holtleltár beszerzés, illetve kiegészítés, mewögazdasági építkezés, ültetvény létesítés, vagy talajjavítás cẻlịából lettek felvéve. Ha a bizottság az adósságokat a törvény értelmében konvertálhatónak nyilvánítja, határozatát megküildi a Banca Agriculturii-nak a konverzió végrehajtása céljából. A Banca Agrieulturii az általa átvett adósságokat 30 éves lejáratú, 8.5 százalékos törlesztéses kölesönné alakítja át, míg a hitelezöket 40 év alatt tördesztendổ 8.5 százalekas nyereménykötvényerkel elégíti ki.

Amennyiben a hitelezők nem jáulnának hozzá követeléseik konvertálásához, az adósnak jogában áll kényszeregyezségi eljárás megindátásắt kérmi az illetékes bíróságtól. A kényszeregyezség során az adôsnak legkevesebb 75 százalékros kielégítést kell felajânlania 30 évi törlesztéssel és 7 százalékos kamattal. A kényszeregyezség el fogadásához az ösz6as tartozissok 25 százalékát képviselö hitelezŏ̉k hozzájarulása szükséges.

A törvénytervezet megjelenését roppant vegyes érzelnoekkel fogadta a közvèleanény. A törvénytervezet teijesen ájszerủ és meglepöen radikális szellemü megoldása oly elönyökhöz juttatja az adósokat a hitelevơk róvására, melyekre még soha és sehol sem volt példa. A közvélemény egy része teljes bizalmatlansággal tekintett a tervezet törvényeröre emelkedése elé, a hitelezők érdekképviseletei azonban rögtön a tervezet megjelenése után minden eszközt megragadtak sérelmezett jogaik védelmére. Im a tervezetet a kiküldött parlamenti bizottság s részben még a parlament is nemhogy enyhítette volna, de még jobban megszigorította a hitelezök rovására. A jogszerinti konverzió alá esö birtokosok kategúriáját 10 holdról 20 holdra emelték fel s a 20 holdon fehïli birtokosok konver. zóo jánál eltörölteł a bizottsági eljáráat, kiküszöböltéck továbbá a Banca 
Agriculturii közremüködését is és háromféle szanálási lehetöséget biztositottak számukra. Míg a tervezet eredeti szövege szerint a jogszerinti konverzió alá eső adósok hitelezöit az állam, a 10 holdon felüli konvertált birtokosok hitelezöit pedig a Banca Agriculturii elégítette volna ki, a törvény ezt a megoldást teljesen törölte $s$ arra kötelezi a hitelezöket, hogy követeléseik visszafizetését 30 évi törlesztéssel fogadják el közvetlenül az adósoktól. A mezőgazdasági adósságok konverziójából tehát lé. nyegében adósságleszállítással kombinált tartozásátalakitás (nováció) lett. Ezért a törvény végleges szövegében a konverzió szó helyett leggyakrabban az "adósságrendezés" kifejezést alkalmazzák, amelyet a tờrvény címébe is felvettek.

Míg a törvénytervezet elökészítö munkálatai folytak, a világjelen. ségként fellépö bizalmiválság következtében kirobbant run a román pénzpiacon is végigvonult, ami még fokozottabb szigorral kényszerítette a bankokat követeléseik behajtására. Hogy a kormány a már teljesen fiizetöképtelenné vált és végsökig elkeseredett gazdatársadalmat addig is, mig a konverziós törvény életbe nem lép, megmentse a teljes anyagi összeomlástól, moratóriumot rendelt el a mezőgazdasági adósságokra.

\section{A mezögazdasági adósságok moratóriuma.}

A mezőgazdasági adósságok moratóriumára vonatkozó 1931. évi december 18-i törvény mindennemü mezőgazdasági adósságra nézve 1932. évi február 15-ig moratóriumot rendel el. A moratórium idötartama alatt a hitelező esak oly magas kamatot számíthat fel, mint a Banca Nationala mindenkori visszleszámitolási kamata. A hitelező követelése biztosítása érdekében foglalásokat eszközölhet, de az ingók elszállításával kapesolatos végrehajtás tilos, kivéve az adók behajtását, illetve biztosítása érdekében a kinestár részéröl folyamatba tett végrehajtásokat. Oly megterhelések és elidegenítések pedig, melyek a moratóriumra kényszeritett hitelezök megrövidítését eredményeznék, semmisek.

Minthogy a mezögazdasági adósságok konverziójáról szóló törvényjavaslat tárgyalása az elöre nem látott viták folytán rendkívül hosszú idöt vett igénybe, a moratóriumot két ízben is meg kellett hosszabbítani. A moratórium meghosszabbítására vonatkozólag először az 1932. évi február 13-i törvény intézkedett, mely a törvény hatályát március 15-ig terjesztette ki, majd az 1932. évi március 12-i törvény május 1-ig prolongálta a moratórium hatályát.

\section{A mezőgazdasági adóssảgok rendezéséról szólỏ 1932. évi április 19-i törvény.}

A mezögazdasági adósságok konverziójáról szóló törvényt hosszas és szenvedelmes parlamenti viták után 1932. év április 19-én hirdették $\mathrm{ki}$, azonnali hatállyal. A törvény lényege - mint említettük - az adósságleszállítás és a tartozásátalakítás. Az adósságleszállítáist avval indokolja a törvény, hogy a mezögazdasáig tejesítőképességén felül való el- 
adósodása a túlmagas kamatok felhalmozódásából állott elö, mert a gazdák nemhogy törleszteni nem tudtak, de lecsökkent jövedelmük folytán még a kamatokat sem tudták megfizetni, amelyeket a hitelezők igy évröl-évre tökésítettek. Indokolt tehát a felhalmozódott kamatokkal megnövekedett tartozások oly mértékben való leszállítása, mint amilyen mértékben azt a kamatok felhalmozódása megnövelte. Az adósságelengedés mellett szól az a körülmény is, - bár ezt a miniszteri indokolás nem említi - hogy a deflációs pénzügyi politika következtében minden téren nagy áresés következett be, tehát a pénz vásárlóereje megnövekedett $s$ így végeredményben az adós számszerủleg lecsökkentett adóssága ma ugyanakkora értéket képvisel, vásárló erövel bír, mint a kölcsön felvétele idején a számszerüleg nagyobb összeg. Sokkal helyesebb lett volna, ha az adósságelengedést nem a kamathalmozással, hanem az átértékeléssel, a revalorizációval, indokolja meg a törvény. Bár a körülmények adottságában a mezögazdasági adósságok hosszúlejáratú törlesztéses kölesönné való átalakítása semmi különösebb indoklást nem kíván. nagy hibája a törvénynek, hogy mikor a hitelezőket követeléseik hosszúlejáratú törlesztéses kölcsönné való átalakítására kényszeríti, nem gondoskodik kielégítỏ módon arról, hogy a hitelezők követeléseik legalåbb egy részét mobilizálhatóvá tehessék. Ebben a tekintetben mindössze csak annyit tesz, hogy felhatalmazza a bankokat a jogerös bírói határozattal megállapított kơveteléseik erejéig az Amortizációs Pénztár útján való jelzálog-kötvények kibocsátására. Kérdés azonban, a kötvényeket mikor és hogyan lehet majd értékesíteni. Minthogy a vidéki pénzintézetek kihelyezéseik legnagyobb részét éppen a mezőgazdasági hitelellátás hiányossága folytán mezőgazdasági kölicsönök teszik, a konverzió fenti megoldása a bankok teljes immobilitását vonja maga után, ami hosszú idöre lehetetlenné teszi, hogy hitelellátó faladatukat betölthessék.

Az 1932. évi április hó 19-i mezőgazdasági adósságok rendezéséről szóló törvény az adósságrendezés négy kategóriáját különbözteti meg: a jogszerinti tartozásrendezást, a halmozott kamatok leszállítása útján való tartozásrendezést, a bírói tartozásrendezést és a végrehajtás elhalasztása útján való tartozásrendezést.

A jogszerinti tartozásrendezés alá esnek a 20 holdnál nem nagyobb birtokkal rendelkező gazdák adósságai, ha mezőgazdasági ingatlanaik (szántók, rétek, legelő̉k, szölők, gyümölcsös- és veteményeskertek, erdők, csemetekertek) értéke legalăbb összvagyonuk értékének $30 \%$-át teszi ki. Az ebbe a kategóriába tartozó gazdák adósságai a törvény közhírré tételének pillanatában jogszerúen $50 \%$-al szállíttatnak le és évi 4\%-os kamatozású, 30 éves lejáratú törlesztéses kölesönné alakulnak át. Az évi részletek minden év október havában esedékesek és azok köz. adók módjára hajtatnak be, ha csak az adós az esedékes részletet nem fizette meg közvetlenül a hitelezőnek. Az esedékes évi nészlet elmulasztásának esetén csakis a birtok jövedelmére vezethető végrehajtás, 3 évi hátrálék esv tében azonban jogában áll a hitelezőnek magára a birtokra is végrehajtást vezetni. Kivétel mind az elóbbi, mind az utóbbi esetben a véletlen, vagy erỏhatalmi gátlás, mikor is a bíróság a teljesítésre haladékot aduat. 
A jcgozerinti tartozásrendezés alá esb̆ adósok hibelezői lötelesek a tōrvény kihirdetésétö́l számított 3 hónapon belül az adós lakbølyo sze rint illetékes járâsbiróságnál bejelenteni követeléseiket, különber elesnøk azon jogtól, hogy követelésüket az adós birtokára, annak élö és holt felszerelésére vagy terményeire érvényesíthessék. A birósâg a követelé sek és a vita tárgyává tett ügyek kérdésében egyszerü határozattal dönt $s$ jövőre nézve ez a hitelezö követelésének jogalapja.

A jogszerinti tartozásrendezés elönyeit élvezhetik a 20 holdnál nagyobb terjedelmü földbirtokkal rendelkező gazdák is, ha kérésüket csok birtokuk 20 holdját terhelő adósságokra korlátozzák és kijelentik, hoggy tulajdonuk többi részét átengedik a hitelezőknek a magánjog søabâlyai szerint való végrehajtás céljára. Ebben az esetben a bírôság határozza meg azt a hânyadrészt, mely az össztartozásokból a felajânlott 20 holdra eeik, különben a 20 holdon felüli birtokosok tartozásrendezéee a leszállítás útján való tartozásrendezés, a bírói tartozásrendezés vagy a végrehajtás elhalasztása útján való tartozásrendezés által történik.

A tartozásrendezés fenti hărom módjának valamelyikét a 20 holdnál nagjobb birtokkal rendelkező gazdák mindazon tartozásaik rendezésére igenybevehetik, amelyek 1931. december 18-a elött (mezőgazdasági adóssáøok moratóriuma) keletkeztek és az össztartozásaik legalább 60\%-a földszerzés, élö- és holtleltár beszerzése, illetve kuegészítése, gazdasági épületek, ültetvények, termöföldjavítások, gátak és alagesövezések, öntözóberendezések létesítése, a gazdálkodásból eredt károk pótlâsa, a létminimum bintosítása, avagy erỏhatalom által okozott károk vagy termelési költségek fedezésére használtattak fel. A tartozảsrendezês fenti módjait igénybe vehetik a 20 holdnál kisebb birtokkal rendelkezó gazdúk is, ha nem esnek a jogszerinti tartozásrendezés alá, vagy ha azt igénybevenni nem akarják, de a fentebbi feltételeknek megfelelnek.

\section{A halmozott kamatok leszállitása útján való tartozásrendezés szerint}

az 19æ1. évben keletkezett tartozások a tőke, kamat és jảrulékai 10\%-ával az 1930. évben keletkezett tartozások a tőke, kamat és járulékaì 20\%-ával az 1929. évben keletkezett tartozások a tőke, kamat és járalékai 30\%-ával as 1928. évben keletkezett tartozások a töke, kamat és járulékai $40 \%$-ával aะ 1927. évben vagy azelött keletkezett tartozások a tőke, kam. és jár. 50\%-ával

esökkentetnek le, ha az adós kötelezi magát a lecsökkentett tartoxás $10 \%$-ának a birói határozat keltétỏl számított 6 hónap alatt való, a hótralékoknak pedig 2 éven belül való megfizetiésére. A tartozásrendezésre jogosultaknak erre irányuló kérésüket az illetékes törvényszékhez kell benyujtaniok, mégpedig a törvény kihirdetésétől számított 60 nap alatt. A törvényszék az adós és hitelezők meghallgatása után határozatban dönt a tartozás leszállításának mértékérỏl és a hátralék esedékességének megállapításáról. $\mathrm{Ha}$ az adós a hátralékos részleteket esedékességükkor nem fizetné meg, ez a tartozásrendezés kedvezmenyének elvesztését vonja maga után s a hitelezỏ a magínjog szabályai gzerint szerezhet kielégitést magának. 
A bírói tartozásrendezés a esödönkíviuli kényszeregyezségre emlékeztető eljárás. A tartozásrendezésre jogosultaknak tartozásaik $60 \%$-át kell felajánlaniok hitelezőik kielégítésére, mégpedig oly módon, hogy az évi törlesztési részleteket az adós évi jövedelmének legalább $50 \%$-a tegye és a törlesztés 30 évet ne haladjon meg. Felajánlhatja azonban az adós teljes jövedelmét is az adósságtörlesztésre, söt bármely más személy szavatosságát. A jövedelem kiszámításánál a kincstári becslések veendők alapul.

A bírói tartozásrendezésre irányuló kérést a törvény kihirdetésktől számított 2 hónapon belül kell az adósnak az illetékes törvényszéknél benyujtania. A kérésnek tartalmaznia kell az adós tartozásainak és követeléseinek kimutatását, azoknak természetét, jogeímét, rangsorát, a tartozások biztosítékát, valamint az adósság törlesztési tervezetét.

A törvényszék a kérés beérkezése és a felek meghallgatása után dönt arról, hogy a kérésnek a törvény rendelkezése szerint hely ad. ható-e. s ha igen, határozatában megállapítja a tartozás végsỏ összegét, a kiegyenlítés határidejét, a törlesztési részleteket, a kamatot (mely a Banca Nationala mindenkori kamatlábánál nagyobb nem lehet) s a tartozúsrendezés biztosítékául szolgáló javakat.

$\mathrm{Az}$ adósok a törlesztési tervezeten a bírói határozat után is módosíthatnak, ha a megajánlott kvótát és a bizosítékokat nem esökkentik, vagy ha a fizetési határidőt nem hosszabbítják meg.

Egyetlenegy törlesztési részlet elmulasztása jogot ad a hitelezőknek arra, hogy a tartozásrendezési határozat megsemmisítését kérjék a híróságtól, mely esetben a hitelezők visszanyerik régi jogaikat s azokat a magánjog szabályai szerint érvényesíthetik. Rossz termés vagy erőhatalmi gátlás esetén az adós bírói haladékot kérhet, $\mathrm{s}$ ez esetben az esedékes részletek felosztatnak a még hátralevő időre.

Az adósoknak és hitelezỏknek jogukban áll a leszállítás útján való és bírói tartozásrendezés szabályai szerint való tartozásrendezésben magánúton is megegyezni s ebben az esetben megállapodásukat csupán hatósági érvényesités végett jelentik be az illetékes tö̈rvényszékhez.

A végrehajtás elhalasztása útján való tartozásrendezés. A tartozásrendezésre jogosult 20 holdnál nagyobb birtokkal rendelkezỏ gazdák, akik nem vehetik vagy nem akarjăk igénybe venni a leszállítás útján való vagy a bírói tartozásrendezést, kérhetik az illetékes törvényszéktöl o.z ellenuik vezetett kielégítési végrehajtások elhalasztását a bírói tartozásrendezési eljárás szabályai szerint, azon feltétellel, hogy kötelezik magukat adósságaik három év alatt való megfizetésére a Banca Naţionala kamatlábának megfelelő kamat mellett. A kamat megfizetésének elmalasztáisa a tartozásrendezés kedvezményének elvesztését vonja maga után.

Mindazon adósok, akik jelen törvény alapján tartozásrendezésben részesültek, kötelesek a földmivelésügyi minisztérium által részükre megállapítandó termelési tervezet szerint folytatni gazdálkodásukat. 


\section{A. mezōgazdasági adósságok rendezéséról szóló törvény módasitása.}

A mezögazdasági adósságok rendezéséröl szóló törvény alapján történt konverziós bejelentések után országszerte folyamatba tették a bírói eljárásokat. Sok helyen már a tárgyalâsokat is megindították, mikor a hirtelen bekövetkezett kormányváltozás ismét felborította az egész konverziós múveletet. Az új kormány ugyanis az ország pénzügyi szanálása érdekében népszövetségi kölcsönért folyamodott. A Népszövetség által kiküldött szakértök a kölesön folyósíthatóságának kardinális elöfeltételei közt azonban a mezögazdasági adósságok konverziójának az elejtését is követelték, s a konverziót csupán a tartozások kamataira vonatkozólag tartották megengedhetönek. Mivel az új kormány programmját a népszövetségi kölcsön nélkül nem tudta megoldani, kénytelen volt a szakértök, illetve azokon keresztül a külföldi tökeérdekeltségek nyomácának engedni és a folyamatba tett konverziós eljárásokat felfüggeszteni. Természetes azonban, hogy a mezögazdasági adósságok rendezésének kérdését nem lehetett tovăbbra is nyitva hagyni, oly megoldást kellett tehát keresni, mely mind a külföldet, mind a belföldet egyaránt ki. clégiti. Toy jött létre a mezögazdasági adósságok rendezéséröl szóló 1932. évi április 19-i törvényt módosító 1932 . évi október 26-i törvény.

A fenti törvény a mezőgazdasági adósságok rendezéséről szỏló 1932. évi április 19-i törvény végrehajtását felfüggeszti másfél évre, mely idő ilatt a mezögazdasági adósoknak moratóriumot nyujt. Ezen idő alatt a bíróság akár az adós, akár a hitelezö kérelmére köteles az 1932. évi április 19-i törvény alapján benyujtott konverziós kéréseket tárgyalás alá verıni annak megállapítása céljâboól, hogy az adós és tartozásai megfelelnek-e az említett és jelen törvény rendelkezéseinek. Ha az adós megfelel az említett törvények rendelkezéseinek, úgy adósságai tekintetében 6 havi moratóriumot élvez, mely idő alatt sem kielégítési végrehajtást, sem biztosítási intézkedéseket nem lehet ellene foganatosítani, kôteles azonban váltóit újabb 6 havi lejáratra szóló váltókkal kicserélni. A 6 hónapi moratórium alatt a 20 holdon aluli birtokosok az 1932. évi április hó 19-i törvény szerint leszállított tartozásaik után 4\% kamatot, a 20 holdon felüli birtokosok pedig tartozásaik teljes összege után $5 \%$ kamatot kötelesek fizetni. Ezek a kamatok a törvény kihirdetésétöl számítotł 6 hónap elteltével követelhetök $\mathrm{s}$ nemfizetés esetén behajtásuk végett vég!’ehajtás kérhetö, melvet minden bírói ítẻlet nélkül az illetékes törvényszék elnöke rendel el. A kamatkövetelések behajtása céljából foganatosított végrehajtás esakis az adós termésére vagy ingó jószágaira vezethető. Amennyiben az adós a 6 hónap lejártáig nem adna csereváltót. úgy mind a jelen törvény, mind pedig az 1932. évi április 19-i törvény kedvezményeit elveszti. Ha az adós fenti 6 hónap elteltével nem vesztette el a konverzióra való jogát a törvény kedvezményébỏl való bírói határezat útján történt kizárás folytán. úgy további 12 havi moratóriumot èlvezhet avval a feltétellel, hogy újabb 6-6 havi lejáratra szóló váltót ad át hitelezöinek. Ezen idötartam alatt a 20 holdon aluli birtokosok leszállított tartozásaik után 4\%, a 20 holdon felüli birtokosok pedig ererleti tartozásaik összege után a Banca Naţionala kamatlábával 
egyenlö kamatot tartoznak fizetni. A váltók fenti idötartama alatt valo meg nem újítása a törvény kedvezményeinek elvesztését vonja maga után.

Jelen törvénynek a mezögazdasági adósságok rendezéséröl szólỏ 1932. évi április 19-i törvény módosítására vonatkozó leg.jelentösebb intézkedése a konverzióra jogosult birtokosok kategóriájának megszorítása.

Míg az 1932. évi április 19-i törvény értelmében mindazon 20 holdon aluli birtokosok, kiknek mezögazdasági ingatlanaik értéke összvagyonuk értékének legalább 30 százalékát teszi ki, a jogszerinti konverzió alá eső birtokosok kategóriájába tartoztak, jelen törvény módosítása folytán csak az alábbiak részesüllhetnek abban:

a) a 20 holdon aluli földmunkás mezögazda adósok, tekintet nélkül arra, hogy egyéb feltételeknek megfelelnek-e;

b) azon 20 holdon aluli földmüvelö mezögazdasági adósok, akik földjüket saját kezelésben, vagy részesmüvelésben mủvelik, $\mathrm{s}$ jövedelmük 80\%-a mezögazdasági tartozás;

c) a mezőgazda adósok. Ilyeneknek tekintendők a papok, tanítók, kisiparosok, parasztmalmok tulajdonosui, továbbá falusi községi tisziviselők és nyugdíjasok, ha földmüvelök és 20 holdnál nagyobb birtokuk niresen;

d) a hegyvidéken fekvő hegyi tisztások, legelök és erdöknek az erdőtörvény értelmében társasággá alakult részes tulajdonosai, továbbá a közbirtokosság tagjai, ha a társaságban nines 20 holdnál több müvelhetó földjük és ha a részes társaságbani, vagy közbirtokossági tulajdonaikból évente 10.000 lejnél nincs tobb jồvedelmük;

e) azon falusi adósok, akik az agrárreform útján állandó jelleggel birtokba helyeztettek, azonban igényjogosultságuk még nem végleges, és akiknek a jelen törvény kihirdetése időpontjában nines tulajdoni jogcímük, de telkük birtokába jóváhagyólag hehelyeztettek.

Az $a$ ) és b) pont alatt felsoroltak azonban esak akkor részesülhetnek a törvény kedvezményében, ha a nem mezőgazdasági birtokaik értéke nem haladja meg mezögazdasági tartozásaik összegét és ha 1931. évi január hó 1-e elött nem voltak földadóval megróva, vagy ha tulajdonosaik birtokukat az ezen időpont után megnyilt hagyatékok kivételével 1931. év január hó 1 . után szerezték.

A törvény fentebbi intézkedése számos kisgazdát rekeszt ki a jogszerinti konverzió elönyéböl, akik különben az 1932. évi április 19-i tör. vén vértelmében élvezték volna azt. Még szigorúbb megszorításban részesült azonban a 20 holdon felüli gazdák kategóriája.

A 20 holdon felüli birtokosok, valamint a jogszerinti konverzió elönyeiben nem részesedhető 20 holdon aluli gazdák csak akkor vehetik igénybe a mezögazdasági adósságok rendezéséről szóló és a jelen tö̀vény kedvezményeit, ha megfelelnek az alábbi követelményeknek:

A) tartozásaik mủvelhetö földjeiknél (szántó, legelő, kaszáló) hektäronként a 20:000 lejt, gátakkal, töltésekkel védett, valamint alagesövezett, öntözött területeknél és gyümölesös ültetvénveknél a 35.000 lejt. szölöknél a 70.000 lejt, erdöknél pedig a 35.000 lejt nem haladja meg. Ez 
a megszorítás nem alkalmazható a földvásárló társaságok földvásárlásból eredö tartozásaira.

B) igazolniok kell, hogy az eredetileg kölcsön vett töke (kamatok nélkül) $80 \%$-a földszerzésre, mezőgazdasági beruházásokra, élö vagy holtleltár létesítésére, illetve szaporítására, mezögazdasági építkezésekre, falusi lakóházak építésére, ültetvények létesítésére, talajjavító beruházásokra, öntözöberendezésre, gátak, töltések, alagesövezések létesítésére és oly tủz, jég, fagy, vagy szárazság által okozott károk fedezésére fordíttatott, melyek a termés $80 \%$-át megsemmisítették.

$\mathrm{Az}$ alaptörvény szerint mindazon 20 holdon felüli birtokosok igénybevehették a konverziôt, akiknek össztartozásaik legalább $60 \%$-a mezögazdasági jellegü volt, ideszámítva a gazdálkodásból eredt károk pótlása, valamint a létminimum fedezése céljából felvett kölesönöket is, míg a jelen törvény termelési ágak szerint holdankénti adósság-maximumot állít fel elöfeltételként, azon felül megköveteli, hogy az adósságok $80 \%$-a mezögazdasági jellegü legyen, nem ismerve el ilyennek a létminimum fedezése céljából felvett, valamint a gazdálkodásból eredt károk pótłására felvett kölcsönöket, ha csak a tủz, jég, fagy, vagy szárazság által okozott károk nem semmisítették meg a termés 80\%-át. Ezek a szigorú megszorítások számtalan önhibáján kívül, a körülmények rendkívülisége következtében eladósodott gazdát zár ki a konverzió lehetöségéből.

A moratórium tartama alatt a gazdák magánegyezséget köthetnek hitelezöikkel, kölcsönösen megállapodva a tartozás végösszege és a kiegyenlítés módozata tekintetében. A adósoknak módjukban áll továbbá tartozásaik rendezése céljából ingatlanaikat a törvényszék engedélyével árverésre bocsátani. Ebben az esetben az árverés az önkéntes árverések szabálya szerint megy végbe, de a kikiáltási árat a törvényszék állapítja meg, $\mathrm{s}$ az osztja fel a vételárat a hitelezők között. Ha a 20 holdon aluli adósok a moratórium tartama alatt töketörlesztést eszközölnek, a törlesztett összeg kétszeresen számít javukra, a hitelszövetkezetekkel szemben másfélszeresen.

Teljesen ki vannak zárva a konverzióból azok az adósok, kiknek adóssága nem tesz ki többet a holdankénti 150 lejnél, szövetkezetekkel szemben pedig 300 lejnél. Bankok, szövetkezetek és kereskedelmi vállalatok igazgatói, igazgatósági és felügyelőbizottsági tagjai, valamint fötisztviselői cégükkel szemben fenálló mezögazdasági tartozásai tekintetében csak az intézetnél levö tőkéjük vagy betétjük erejéig vehetik igénybe a törvény kedvezményét. Eltörli végül a módosító törvény az alaptörvény azon intézkedését, mely szerint a konverzióban részesült gazdák a földmívelésügvi minisztérium által meghatározott elóírás szerint kötelesek földjüket megmủvelni s hatályon kívül helyezi az alaptörvény mindazon intézkedését, amely a jelen törvénnyel ellentétben áll.

A módosító törvény éppen ellentétes célt szolgál az alaptörvénnyel szemben. Míg az alaptörvény az adósokat védte a hitelezökkel szemben, a módosító törvény legföbb törekvése az, hogy az alaptörvény által az adósoknak juttatott elönyökböl, amit csak lehet, visszaszerezzen a hitelezők javára, minthogy az alaptörvényt teljes egészében már nem lehe. 
tett visszavonni. A kormány a módosító törvény megalkotásakor két tüz közé, a kül- és belpolitikai érdekek közé került, melyeket egyformán kellett honorálnia, hogy az ország konszolidációját és a szanálás lehetöségét biztosíthassa. Az eredmény azonban se jobbra, se balra nem megnyug tató. Az egész módosító törvény azt a benyomást kelti, hogy tisztán átmeneti intézkedés, míg a mezögazdasági adósságok rendezésére az eddigi alapelvektöl eltérố, teljesen új alapot nem találnak, vagy az egész kérdést valahogy el nem ejtik, - mert hogy az alaptörvény szerint való kcnverzió sohasem lesz keresztülvihetö, az nyilvánvaló. İgazságos és a gazdasági élet normális menetét biztosító konverzió csak úgy lesz lehetséges, ha az állam mind az adóst, mind a hitelezőt megvédi a károsodástól, (a mostani megoldás mellett az egyik feltétlenül kárt szenved) s oly megoldást alkalmaz, hogy a hitelezö a legrövidebb idő alatt követelése birtokába juthasson. Különben a hitelélet évtizedekre megbénul.

\section{III.}

Ha végigtekintünk a mezőgazdasági hitelkérdés rendezése érdekében alkotott törvények sorozatán, sajnálattal kell megállapítanunk, hogy azok legnagyobb része nem tudott céljának megfelelni. Ennek oka az ország tökeszegénységében és helytelen közgazdasági politikájában rejlik. $\mathrm{Az}$ ország mezögazdasági eladósodása soha sem öltött volna oly katasztrófális méreteket, ha az első magánföldhitelintézeti törvény megalkotásakor a törvényhozás honorálja a külföldi töke kívánságait s szabad útat biztosít számára. Abban az idöben még intenziven érdeklödött a külföld a román piac iránt, $\mathrm{s}$ ha a kormány nem zárkózik el a törvény módosítása elöl, mezögazdaságunk hitelszükségletét rentábilis hitellel lehetett volna kielégíteni. Ám az ország gazdaságpolitikájában akkor még az elzárkózás elve, a prin noi insine jelszava uralkodott, bár nyilvánvaló volt, hogy a belföldi töke kamatait nem tudja elviselni mezögazdaságunk. Mikor az elzárkózó közgazdasági politikával felhagytak, már késö volt. Hiába módosították a magánfởldhitelintézeti törvényt a nemzeközi pénzpiac korábban hangoztatott kívánsága szerint, az ország hitele már meg volt rendülve, a külföldi tőke bizalmát nem lehetett többé visszaszerezni, aminek hiánya már az állami érdekeltségvállalással alapított Creditul Agricol Ipotecart is képtelenné tette feladata betöltésére.

Ekkor, hogy a mezögazdaságot megmenthessék válságos helyzetéböl, repressziv intézkedésekkel igyekszenek a mezögazdasági hitelkérdést megoldani. Megjelenik a kamattörvény, az agrármoratórium $\mathrm{s}$ a különbözỏ konverziós törvények, melyek azonban csak a kór továbbterjedését akadályozták meg, a nélkü̉, hogy a bajokat orvosolni tudták volna.

Eladósodott mezögazdaságunk most itt áll súlyos terheivel, a nélkül, hogy tudñá, mikor és hogy fog azoktól megszabadulni, s a nélkül, hogy a termelés továbbviteléhez szükséges legcsekélyebb kölcsönhöz is hozzá tudna jutni. A törvényhozás a legutóbbi törvény meghozatalakor ismét arra az álláspontra helyezkedett, mint az első magánföldhitelintézeti törvény megalkotásakor, mikor a mezőgazdasági hitelellátást magukra a gazdákra bízta. Most 18 hónapi moratóriumot ad s hangsúlyozza, hogy 
ezen idő alatt igyekezzenek az adósok és hitelezőkkel közvetlenül megegyezni a tartozásrendezés kérdésében. Amint azonban a mezögazdasági hitelellátást sem sikerült annak idején az állam közremủködéso nélkül megoldani, a konverziót sem lehet a nélkül keresztülvinni, s amilyen nagy mértékben súlyosbította a helyzetet a kérdés felületes kezelése akkor, ugyanúgy súlyosbitja az a jelenben is. Pedig a kérdés eredményes megoldását az ország gazdasági érdeke egyre parancsolóbban követeli. Románia, mint agrárállam, a mezögazdasági hitelkérdés rendezése nélkül soha sem fogja tudni a gazdasági élet konszolidációját megteremteni.

Arra a kérdésre, hogy a mezögazdasági adósságok összege végeredményben mennyit tesz ki, sajnos, nem tudunk felelni, mert bár a konverzió kérdésével már közel két éve foglalkozik a törvényhozás, a mezögazdasági adósságok statisztikáját még mindig nem készítették el. A kc:nverziós bejelentéseken alapuló becslések szerint 50 milliárdot is meghaladna a mezögazdasági adósságok végösszege. Jellemzö azonban a mezögazdasági eladósodás súlyos helyzetére, hogy az agrármoratórium óta teljesen megbénult az ország hitelélete, mert az agrárkihelyezések behajthatatlansága teljesen immobilizálta az ország hitelszervezetét.

Kétségtelen, hogy a mezögazdasági eladósodás mai súlyos helyzetében $\mathrm{s}$ különösen a jelenlegi rendkívüli körülmények közt, nehéz feladat a mezögazdasági eladósodás szanálásának helyes esközeit meg. ta!álni, de a kérdés megoldása, éppen annak súlyosságánál fogva, az ország belső gazdasági válságának kivezetö útját jelenti. 


\section{TA A T L I M}

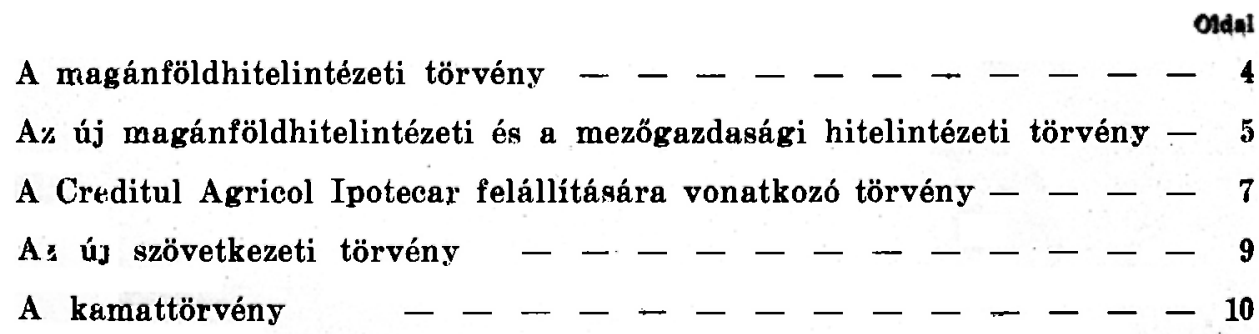

A Hanca Agriculturii Româneşti felállításáról szóló törvény és a mezőgazdasági adósságok konverziója $\quad-\quad---_{-}-11$

A nıezŏgazdasági adósságok moratóriuma - - - - - - 14 A mezögazdasági adósságok rendezéséről szóló 1922. évi április 19-i törvény 14 A mezögazdasági adósságok rendezéséröl szỏló törvény módosítása -18 
EME 


\section{AZ ERDELLY MÚZEUM}

az Erdélyi Múzenm·Egyesület kiadásában jelenik meg évenként 12 számban negyedévenként 7-71/2 ív terjedelemben. A folyóirat az EME Bölcsészet-. nyelv- és történettudományi, Természettudományi-, Orvostudományi- és

Jog- és társadalomtudmányi Szakosztályának hivatalos közlönye.

\section{AZ ERDÉLYI MÚZEUM-oT}

az Egyesület alapító, Igazgatósági és rendes tagjai évi 300 lejes kedvezményes áron kapják. Eilófizetési ára nem tagoknak és könyvkereskedőknek 400 lej. Elöfizetések és a lap szétküldésére vonatkozó kívánságok címe:

ERDELYI MĆZEUM Fiadóhivatala, Cluj-Kolozsvár, Strada Baron L. Pop (volt Brassai-utca) 5.

Kéziratok, ismertetésre szánt könyvek és a folyóirat szellemi részét illetơ tudakozódásuk a szerkesztốt illetik:

DR. GYORGY LAJOS, Cluj-Kolozsvár, Str. Universitătii (v. Egyetem-u.) 10.

A szerkesztčség közli az igen t. munkatársakkal: 1. Géppel írott kéziratokat kér. 2. A közlessre szánt dolgozatok átlagos legnagyobb terjedelme 1 ív. 3. Minden munkatárs a folyóiratnak egyszersmind előfizető́je is. A tiszteletdíjat 300 illetỏleg 400 lejig a kiadóhivatal az előfizetés javára írja. 4. Különnyomat a szerző kivánságára és költségére készül. 5. Kéziratokat a szerkesz-

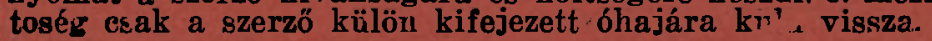




\section{Az Erdélyi Tudományos Füzotek.}

Bzerteszti : Dr. Gjorbs Iajos.

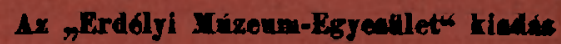

1. Rass Károly: Reményik Sándor - - - - - - - - -

2. Parvan Bazil: A dákok Trójában - $--\ldots$

3. Dr. Bitay Arpád: Gsulafehérvár Erdély müvelödéstörténetében - 30.-

1. Dr. Bitay Arpad: A moldvai magyarság - $-\ldots-\ldots$

5. Szokolay Béla: A nagybányai múvésztelep $-\ldots+-\ldots$

6. Dr. Balogh Ernô: Kvarc az Erdélyi Medence felső mediterrán gipszeiben

7. Dr. György Lajos: Az erd. magyar irodalom bibliografiája. 1925. év

8. $K$. Sebestyén József: A brassai fekete templom Mátyás-kori címerei

9. Dr. Karácsonyi János: Ưj adatok és új szempontok a székelyek régi történetéhez

10. Dr. Gál Kelemen: Brassai küzdelmei a magyartalanságok ellen -

11 Dr. Tavaszy Sándor: Erdélyi szellemi életünk két döntő kérdése -

12. Dr. Gyơrgy Lajos: Két dialogus régi magyar irodalmunkban -

13. $K$. Sebestyén József: A Becse-Gergely nemzetség, az Apafi és a bethleni gróf Bethlen család címere - - - - $---\frac{-}{5}$

14. Dr. Ferenczi Miklós: Az erd. magyar irodalom bibliografiája 1926. év

15. Dr. Gyúrfás Elemér: A Supplex Libellus Valachorum - - - -

16. Rónay Elemér: Kemény János fejedelem halála é nyugvóhelye -

17. Dr. György Lajos: Egy állítólagos Pancsatantra-származék irodalmunkban

18. Dr. Ferencei Miklós: Az erd. magyar irodalom bibliografiája 1927.

19. $\boldsymbol{K}$. Sebestyén József: A középkori nyugati múveltség legkeletibb határai

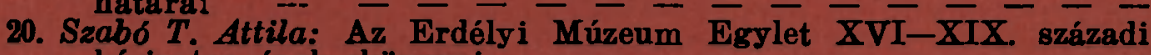
kéziratos énekeskönyvei - - - - - - - - -

21. Dr. Ferenczi Miklos: Az erdélyi magyar irodalom bibliografiája. 1928. év, pótlásokkal az 1919-1928. evekrôl _ _ _ - _ -

22. Dr. Gyơrgy Lajus: A francia hellénizmus hullámai az erdélyi magyar szellemj életben

23. Dr. Kántor Lajos: Az Erdélyi Múzeum-Egyesület problemái - -

24. Dr. Gál Kelemen: A nemzeti nevelés román fogalmazásban - -

25. Dr. Tavaszy Sándor: Kierkegaard személyisége és gondolkozása -

26. Dr. Papp Ferenc: Gyulai Pál id. Bethlen János gr. körében - -

27. Dr. Csíry Bdint: Néprajzi jegyzetek a moldvai magyarokról - -

28. Dr. Biró Vencel: Püspökjelölés az erdélyi róm. kath. egyházmegyében

29. Dr. Teleki Domokos gróf: A marosvásárhelyi Teleki-könyvtár története

30. Dr. Hofbauer Lásalo: A Remény cimü zsebköny v története (1839-1841)

31. Dr. Ferenczi Miklos: Az erdélyi magyar irodalom bibliografiája. 1929. év - - - _ _ _ _ _ _ - _ _ - - -

32. Dr. Gyalui Farkas: A Döbrentei-pályázat és a Bánk bán - - -

33. Dr. Rajka Lászlo: Jókai ,Törökvilág Magyarországon “ c. regénye

34. Dr. Temesváry János: Hét erdélyi püspök végrendelete - -

35. Dr. Biró Vencel: A kolozsmonostori belső jezsuita rendház és iskola Bethlen és a Rákóczy fejedelmek idejében - $-\overline{-}--$

36. Szabó T. Attila: Az Brdélyi Múzeum Vadadi Hegedüs-k6́deze - délyi Múzeum és az Erdélyi Múzeum-Egyesület megalakítása érdekében - - - - - - - - - - - -

38. Dr. Ferencai $\overline{M i k l} \delta s: \overrightarrow{A z}$ erdélyi magyar irodalom bibliografiája. 1930. év - - - - - - - - - -

39. Dr. Balogh Arthur: A székely vallási és iskolai önkormányzat -

40. Dr. György Lajos: Fulenspiegel magyar nyomai — - - - -

41. Dr. Dömötör Sándor: A cigányok temploma - - - - -

42. Dr. Kristóf György: Báró Eötvös József utazásai Erdślyben - -

43. Dr. Hofbauer László: Az Erdélyi Hiradó története - - - -

44. Dr. Kristóf György: Kazinczy és Erdély - - - $->-$

45. Dr. Asztalos Miklós: A székelyek őstörténete letelepülésüikig - -

46. Dr. Varga Béla: Az individualitás kérdése - - - - -

47. Kemény Katalin: Erdélyi emlékirók - - - - - - -

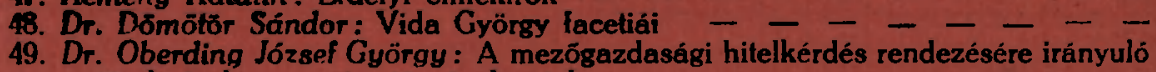
törekvések a román törvényhozásban - - - - - - -50 .

Mecrendelhetők az Erdélyi Múzeum kiadóhivatalában, Cluj-Kolozsvár. Str. Baron L. Pop (volt Brassai-a.) 5. 